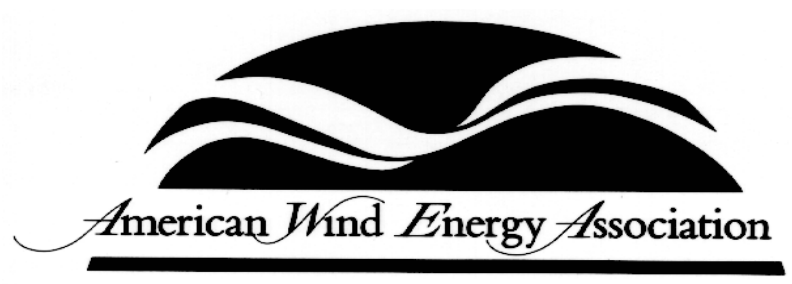

Global Wind Energy Market Report

\title{
Wind Energy Industry Grows at Steady Pace, Adds Over 8,000 MW in 2003
}

\section{World Growth}

Cumulative global wind energy generating capacity topped 39,000 megawatts (MW) and reached 39,294 MW at the end of 2003. New equipment totaling 8,133 MW in capacity was installed worldwide during the year, an increase of $26 \%$, according to estimates by the American Wind Energy Association (AWEA) and the European Wind Energy Association (EWEA). ${ }^{1}$ Wind plants now power the equivalent of 9 million average American homes (19 million average European homes) worldwide.

Growth is widely forecast to continue in the double-digits into the next decade, even as the industry matures. Some $\$ 9$ billion were invested in new wind power generating equipment in 2003, up from \$7 billion in 2002.

Global additions and cumulative wind power capacity (MW) (3)
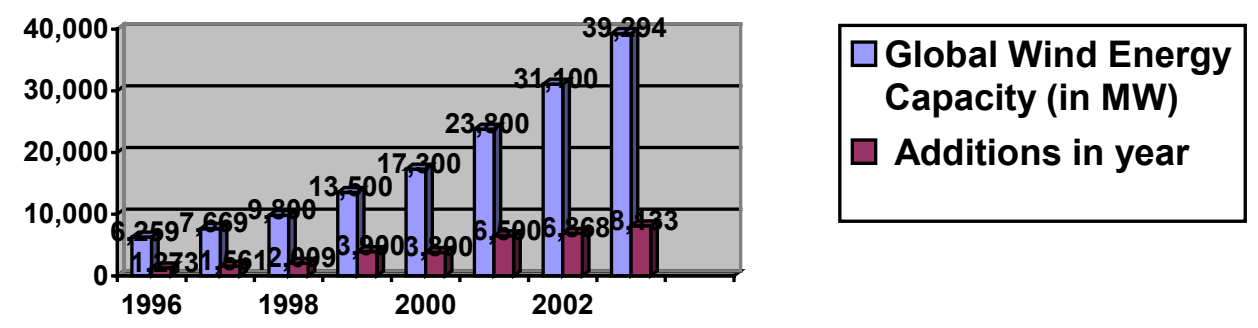

Europe $^{2}$ and the U.S. dominated the market, accounting for nearly $90 \%$ of the new installations. However, that share diminished slightly from 2002, when the two regions accounted for $93 \%$ of new installations. India added an impressive $408 \mathrm{MW}$, the largest single addition outside the European and U.S. markets.

\footnotetext{
${ }^{1}$ Figures are based on year-end national estimates reported by wind and renewable energy associations and other sources.

${ }^{2}$ EU-25 and non-EU European countries such as Norway, Switzerland and Romania.

${ }^{3}$ Due to previous-year adjustments, project decommissionings, and re-powering, end-of-year cumulative capacity totals may not exactly match the year-end total plus additions.
} 


\begin{tabular}{|l|cccc|}
\hline $\begin{array}{l}\text { Top five } \\
\text { wind energy markets } \\
\text { (installed capacity, in MW) }\end{array}$ & $\begin{array}{c}\text { 2002 } \\
\text { Additions }\end{array}$ & $\begin{array}{c}2002 \text { Year End } \\
\text { Total }\end{array}$ & $\begin{array}{c}2003 \\
\text { Additions }\end{array}$ & $\begin{array}{c}\mathbf{2 0 0 3} \text { Year End } \\
\text { Total }\end{array}$ \\
\hline Germany & 3,247 & 12,001 & 2,645 & $\mathbf{1 4 , 6 0 9}$ \\
United States & 410 & 4,685 & 1,687 & $\mathbf{6 , 3 7 4}$ \\
Spain & 1,493 & 4,830 & 1,377 & $\mathbf{6 , 2 0 2}$ \\
Denmark & 407 & 2,880 & 243 & $\mathbf{3 , 1 1 0}$ \\
India & 195 & 1,702 & 408 & $\mathbf{2 , 1 1 0}$ \\
\hline
\end{tabular}

The global wind energy market is consolidating as it is maturing. Vestas, already the world's largest wind turbine manufacturer (20.6\% accumulated market share in 2002 according to BTM Consult), and NEG-Micon, the second largest (17.3\% accumulated share at end of 2002) announced at the end of 2003 that they would merge their operations, creating the world's single largest wind turbine manufacturing group. GE Wind is increasing its market share, and sold more than half of the generating capacity installed in the U.S. in 2003. Gamesa and Suzlon are expanding operations outside of their country of origin and installed their first turbines in the U.S. last year.

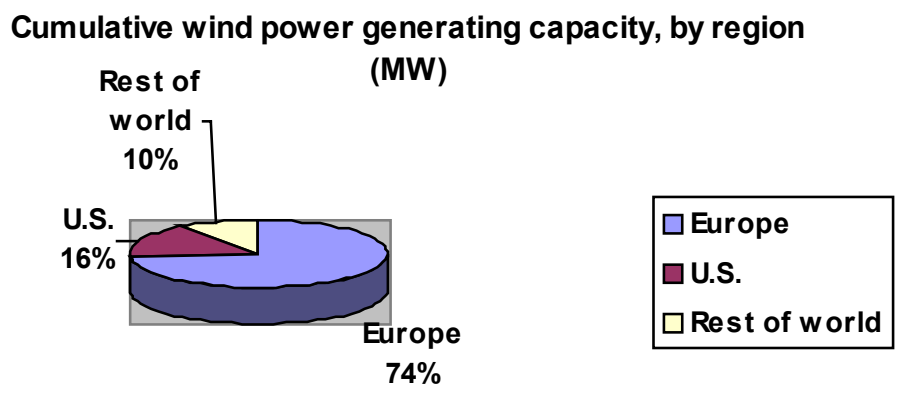

Worldwide, Europe and the U.S. account for $90 \%$ of cumulative capacity.

\section{Regional Highlights}

\section{Europe}

Europe again provided the bulk of the past year's investments. A total of 5,452 MW was installed in the EU-25 countries in 2003, EWEA reports. Total regional wind power capacity grew 23\% to 28,411 MW (EU-15) and 28,706 MW for the broader region (EU-25 and non-member states such as Switzerland, Norway, and the Ukraine).

The 28,401 MW in operation by the EU-15 by the end of 2003 will, in an average wind year, produce 60 terawatthours (TWh), equal to about $2.4 \%$ of total EU electricity 
consumption, according to EWEA. That is enough to power 14 million average European households.

Within Europe, installations remain concentrated in the "big three" (Germany, Spain, and Denmark). The somewhat slower growth in the large German market, which has been expected, is partially offset by noticeable additions from emerging European markets such as Austria (276 MW), the Netherlands (226 MW), Italy (116 MW), Portugal (107 MW) and the UK (103 MW).

Germany: With 2,645 MW of new installations, Germany accounted for almost half of the new capacity installed in the EU-15. The country's wind power capacity now totals 14,609 MW. Germany remains the world's biggest market, in spite of a considerable, and anticipated, decline in its growth rate. In a typical wind year, Germany's wind farms generate enough to meet about $6 \%$ of the country's electricity needs, according to the German Wind Energy Association (Bundesverband Windenergie).

The German wind energy industry currently employs 45,400 people. Wind power generation is concentrated in the northwestern regions of the country: Schleswig-Holstein, where the target of $25 \%$ of power to be generated from wind by 2010 has already been achieved; and other provinces in Northwestern Germany such as Mecklenburg-West Pomerania, Saxony-Anhalt, Lower Saxony, and Brandenburg.

Spain: Spain installed 1,377 MW of new wind capacity, and cumulative generating capacity reached 6,202 MW by year's end. Wind now provides between $4 \%$ and $5 \%$ of the nation's power.

Over the past decade, Spain's wind power fleet has grown from just $52 \mathrm{MW}$ in 1993, in Tarifa across the straits of Gibraltar from Morocco, to over 6,000 MW, operating in several provinces, including Galicia, Aragon, Navarra and Castilla. The fast growth was triggered by a federal requirement that utilities pay a premium price for electricity from wind over the first five years of the project - an incentive similar to the "feed-in" tariff that spurred the German wind energy market. Local governments have also required that a large share of the investments (such as manufacturing and construction) remain in the local economy.

Austria: Austria added an impressive $276 \mathrm{MW}$-- the most new wind power development in Europe in 2003 after Germany and Spain. The new installations bring Austria, which now has a total of $415 \mathrm{MW}$, into the top ten countries by installed wind capacity in Europe - ahead of Sweden, Greece, Portugal and France, all countries that also now have "triple-digit" cumulative capacity. The take-off in the Austrian market is largely attributable to the introduction of a "feed-in" tariff for renewables in January 2003.

Denmark: Denmark installed $243 \mathrm{MW}$ to reach 3,110 MW. Most of the new capacity comes from offshore projects: Rodsand/Nysted (158 MW); Samso (23 MW), and Frederickshaven (10.6 MW). Denmark - a country about the size of Maine - generates some $20 \%$ of its power from wind. It is the nation that gets the highest percentage of its electricity from wind. 
The Netherlands: This small country added $226 \mathrm{MW}$ in 2003. The nation is now nearing the 1,000-MW mark, with a cumulative $912 \mathrm{MW}$ installed.

Italy installed $116 \mathrm{MW}$, and, like the Netherlands, is nearing the 1,000-MW mark with $904 \mathrm{MW}$.

The United Kingdom: In the U.K., the European nation with the largest wind power potential, new installations grew by $103 \mathrm{MW}$ in 2003. The amount of wind power capacity in the U.K. stood at $649 \mathrm{MW}$ at the end of 2003, generating enough to power the equivalent of 441,000 homes. The British Wind Energy Association expects that some 474 MW - about four times the amount installed in 2003 -- will be installed in 2004. More than 2,000 MW of wind development are now permitted in the country, with about half of that amount offshore.

\section{North America}

United States: 2003 came close to being a record-breaking year in the U.S., with 1,687 MW installed, just a few megawatts shy of the 1,696 MW installed in 2001. Current cumulative capacity stood at 6,374 MW at the end of the year, with utility-scale turbines operating in 30 states.

The states leading in cumulative capacity are California (2,043MW), Texas (1,293 MW), Minnesota (563 MW), Iowa (472 MW), and Wyoming (285 MW).

More than half of the new capacity installed consisted of GE Wind turbines. Spanish manufacturer Gamesa and Indian manufacturer Suzlon installed their first turbines in the U.S., both in Minnesota.

The short-term outlook (2004) is uncertain, due to the expiration of the federal production tax credit (PTC) on December 31, 2003, and the failure of Congress to extend the credit in time to ensure continued, orderly growth of the market. An extension of the PTC through December, 2006, is contained in wide-ranging energy policy legislation on which Congress has been unable to reach final agreement at the time of the writing of this report (March 2004). The delay in the PTC's renewal is inflicting a high cost on the industry - initial estimates are that, with a timely extension, some 2,000 MW of new capacity would have been installed in 2004. Instead, projects are on hold pending renewal of the credit.

Less than $1 \%$ of U.S. electricity is generated from wind. Most of the country's power comes from coal (over 50\%), with nuclear (20\%), natural gas (18\%), and hydropower (7\%) making up most of the rest.

Canada: Canada added $81 \mathrm{MW}$ in 2003, according to the Canadian Wind Energy Association (CanWEA). Most of the new equipment was installed in Alberta. Canada's cumulative generating capacity at year's end stood at $317 \mathrm{MW}$. More is expected to be installed in the next few years: in early 2004, the industry was gearing to respond to requests for proposals totaling some 1,000 MW of new wind. 


\section{Rest of World}

Most of the new development in the rest of the world occurred in Asia, mainly in India (408 MW), Japan (272 MW), and China (about 100 MW), and in the Pacific, in Australia (93 MW). India again secured its position as one of the world's top five wind power markets.

India: India added $408 \mathrm{MW}$ in 2003, and now boasts over 2,000 MW of wind power. Expansion of wind power in the country appears to be on a solid footing. Indian wind turbine manufacturer Suzlon installed its first wind turbines in the U.S., and is seeking to expand in the global market.

Japan: Japan added a total of $272 \mathrm{MW}$, bringing cumulative capacity at the end of the year to $686 \mathrm{MW}$.

China: About $100 \mathrm{MW}$ were installed in China, according to preliminary estimates. Total generating capacity in the country is close to $600 \mathrm{MW}$. Wind power development in China remains slow to take off, in spite of this country's vast potential and fast-growing demand for power.

Latin America: Colombia completed its first utility-scale wind project, a 19.5-MW project by the Caribbean coast, on the peninsula of Guajira. The project was made financially possible by being treated as a "technical innovation project," according to Nordex, the manufacturer supplying the turbines for the project. This designation allowed the utility to deduct some of the investment costs from pretax profits. Like many other countries in the region, Colombia has restructured its electricity market; power prices are typically low, and power plants exceeding $20 \mathrm{MW}$ in capacity are required to sell power on the electricity exchange - which puts a variable source like wind at a disadvantage.

A listing of new and cumulative installed capacity by country and by region is included as an appendix.

March 2004 
Appendix: Global Wind Energy Generating Capacity (AWEA and EWEA estimates)

Global wind power installed in 2003

\begin{tabular}{|c|c|c|c|c|}
\hline Country & $\begin{array}{l}\text { Total } \\
\text { installed } \\
\text { during } 2002\end{array}$ & $\begin{array}{l}\text { Total installed by } \\
\text { end of } 2002\end{array}$ & $\begin{array}{l}\text { Total installed } \\
\text { during } 2003\end{array}$ & $\begin{array}{l}\text { Total installed by end of } \\
2003\end{array}$ \\
\hline NORTH AMERICA TOTAL & $\begin{array}{l}450 \\
(6.5 \%)\end{array}$ & $4,921(16 \%)$ & $1,768(22 \%)$ & $6,691(17 \%)$ \\
\hline Canada & & 236 & 81 & 317 \\
\hline USA & & 4,685 & 1,687 & 6,374 \\
\hline EUROPE TOTAL & $5,983(87 \%)$ & $23,308(74.5 \%)$ & $5,467(67 \%)$ & $28,706(73 \%)$ \\
\hline (EU 15 TOTAL) & 5,871 & 23,098 & 5,411 & 28,401 \\
\hline Germany & & 11,994 & 2,645 & 14,609 \\
\hline Spain & & 4,825 & 1,377 & 6,202 \\
\hline Denmark & & 2,889 & 243 & 3,110 \\
\hline Netherlands & & 693 & 226 & 912 \\
\hline Italy & & 788 & 116 & 904 \\
\hline UK & & 552 & 103 & 649 \\
\hline Sweden & & 345 & 54 & 399 \\
\hline Greece & & 297 & 78 & 375 \\
\hline France & & 148 & 91 & 239 \\
\hline Austria & & 140 & 276 & 415 \\
\hline Portugal & & 195 & 107 & 299 \\
\hline Ireland & & 137 & 49 & 186 \\
\hline Belgium & & 35 & 33 & 68 \\
\hline Finland & & 43 & 8 & 51 \\
\hline Luxembourg & & 17 & 5 & 22 \\
\hline (ACCESSION STATES TOTAL) & 29 & 61 & 41 & 102 \\
\hline Poland & & 27 & 30 & 57 \\
\hline Latvia & & 24 & 0 & 24 \\
\hline Czech Republic & & 3 & 7 & 10 \\
\hline Hungary & & 3 & 0 & 3 \\
\hline Estonia & & 2 & 1 & 3 \\
\hline Cyprus & & 2 & 0 & 2 \\
\hline Lithuania & & 0 & 0 & 0 \\
\hline Malta & & 0 & 0 & 0 \\
\hline Slovakia & & 0 & 3 & 3 \\
\hline Slovenia & & 0 & 0 & 0 \\
\hline (OTHER EUROPE TOTAL) & 83 & 149 & 15 & 164 \\
\hline Norway & & 97 & 4 & 101 \\
\hline Ukraine & & 46 & 11 & 57 \\
\hline Switzerland & & 5 & 0 & 5 \\
\hline Romania & & 1 & 0 & 1 \\
\hline REST OF THE WORLD TOTAL & $435(6.5 \%)$ & $2,999(9.5 \%)$ & $898(11 \%)$ & $3,897(10 \%)$ \\
\hline India & 195 & 1,702 & 408 & $2110(5.4 \%)$ \\
\hline China & 68 & 468 & 100 & 568 \\
\hline Japan & 140 & 414 & 272 & 686 \\
\hline Australia & 32 & 105 & 93 & 198 \\
\hline Other countries & - & 310 & 25 & 335 \\
\hline GRAND TOTAL & 6,868 & 31,228 & 8,133 & 39,294 \\
\hline
\end{tabular}

\section{Source: EWEA. AWEA}

Note: Due to previous-year adjustments, project decommissionings, and re-powering, the 2003 end-of-year cumulative capacity total may not exactly match the year-end 2002 total plus the 2003 additions. 
